\title{
COMPARISON OF PROFITS OF EFFECTIVE PORTFOLIOS WITH NON-EFFECTIVE PORTFOLIOS TAKING INTO ACCOUNT THE FUZZY APPROACH
}

\author{
Ewa POŚPIECH \\ Economic University in Katowice; posp@ue.katowice.pl, ORCID: 0000-0001-5015-8875
}

Purpose: The aim of the article is to compare the results of the constructed effective portfolios and non-effective portfolios build on the basis of the value of the indicator constituting a synthetic assessment of decision variants.

Design/methodology/approach: The article uses the multi-criteria TOPSIS method in the standard and fuzzy approach. It was used to evaluate listed companies that were examined in terms of selected fundamental and market characteristics. Taking into account the fuzzy method made it possible to treat the values of criteria from three years as triangular fuzzy numbers, and the values of the measure on the basis of which the ranking was created were also used to build non-effective portfolios.

Findings: A multi-criteria evaluation of selected listed companies was performed and, on the basis of the obtained rankings, the sets constituting the basis for the construction of effective and non-effective portfolios were selected. The designated effective portfolios (after pre-selection using the FTOPSIS method) were in most cases more profitable than the market portfolio, while the non-effective portfolios, using TOPSIS as the pre-selection method, were (with one exception) more profitable than the effective portfolios.

Research limitations/implications: It was not possible to unequivocally recommend the approach used, although the results appear promising.

Practical implications: Taking into account the proposed approach, one can methodically build more profitable and more attractive portfolios.

Originality/value: Non-standard approach to criteria assessments and the use of metacriterion values to determine the portfolio structure. The considerations may be of interest to stock market investors.

Keywords: Effective portfolios, fuzzy TOPSIS, multi-criteria problem, non-effective portfolios.

Category of the paper: Research paper. 


\section{Introduction}

Various methods are used to build equity portfolios. When a long-term portfolio is constructed, fundamental analysis is often used to assess the company and its economic environment. Such an assessment is made on the basis of many indicators characterizing the studied areas. The multitude of available indicators may make the analysis of the issue difficult, so it is worth approaching the problem in a methodical manner: selecting the most important factors describing the company's condition, and then applying the method of ordering objects assessed through the prism of these factors. Such a possibility is provided by the use of multicriteria methods that allow for the ordering of objects assessed in terms of many criteria. The conducted analysis makes it possible to identify companies with the most preferred features by the decision-maker, and based on the obtained set, a portfolio can be built. One of the options for selecting a portfolio is to designate effective portfolios consisting in solving optimization tasks in which, at a given rate of return, the portfolio risk is minimized or, at a given risk level, the portfolio's rate of return is maximized (Jajuga, and Jajuga, 2015). The research made it possible to designate effective portfolios that minimize the portfolio risk, compare them with the results of the market portfolio and, using a non-standard concept, construct non-effective portfolios.

The aim of the article is to compare the results of the constructed effective portfolios and non-effective portfolios built on the basis of the value of the indicator constituting a synthetic assessment of decision variants, as well as a recommendation of the approaches used. The research hypothesis states that the obtained non-effective portfolios may be more profitable for the investor than the effective and market portfolios.

\section{Research methodology}

In the research, to assess the economic and financial situation of companies, the multicriteria TOPSIS method was used in two versions: standard and fuzzy. This method is widely used in a variety of problems and its end result is a ranking of objects. It is possible to distinguish several variants of the method, so it can be used, for example, for variables presented in the form of crisp values, fuzzy numbers, interval numbers, linguistic data and others. The TOPSIS method has also found applications in supporting portfolio selection (Chen, and Hung, 2009; Ece, and Uludag, 2017; Kazemi et al., 2014; Liu, et al., 2012; Nguyen, and Gordon-Brown, 2012; Raei, and Bahrani Jahromi, 2012). The considerations presented in this study are a continuation of previous research in which, by proposing various approaches, 
ways to generate profitable, attractive portfolios for the investor are looked for (Pośpiech, 2017a, 2017b, 2018; Pośpiech, and Mastalerz-Kodzis, 2015, 2016).

In the article, as in previous works, the starting point is the selection of the initial set of companies, assessment of their economic and financial situation (using the TOPSIS methods, where the role of evaluation criteria play chosen fundamental and market indicators), building the ranking and selecting the set constituting the basis for portfolio construction. The ranking was built using the TOPSIS and FTOPSIS methods. Data from three years were taken into account for selected indicators (Tarczyński, 2002). Using the standard version of the method, the mean value for the studied years was determined, while in the case of the fuzzy version, the data from three years were represented as triangular fuzzy numbers $\widetilde{a}_{i}^{(k)}=\left(l_{i k}, m_{i k}, u_{i k}\right)$, where: $k$-specifies the criterion number, $l_{k}$ - the smallest value of the criterion assessment for the company from selected years, $m_{k}$ - the middle value of the criterion assessment for the company from chosen years, $u_{k}$ - the highest value of the criterion assessment for the company from considered years.

The procedure of determining the multi-criteria ranking using TOPSIS methods can be found in many works, including (Hwang, and Yoon, 1981; Jahanshahloo, et al., 2006; Lai, et al., 1994; Roszkowska, and Wachowicz, 2013; Trzaskalik, 2014). Generally, it includes building a decision matrix, its normalization, determination of ideal and non-ideal solutions, calculation of object distances from these points and the relative distance $S_{i}$, on the basis of which the ranking is constructed (the higher the value, the higher the position in the ranking).

Four fundamental and market indicators were selected as evaluation criteria (Leszczyński, 2004; Tarczyński, 2001, 2002; Trzaskalik, 2006; Tyran, 2001):

- return of assets ROA (net income/average total assets),

- return of equity ROE (net income/shareholder equity),

- P/BV (price-book value),

- P/E (price-earnings ratio).

Each of the above criteria was found to be of equal importance and the maximization of each of them was assumed.

As the analyzes are a continuation of previous research, the base set of companies includes those that made up the WIG20 index in December 2017, while the data for the indicators come from 2015-2017. After applying multi-criteria methods and obtaining rankings, effective portfolios were determined using the classic Markowitz approach (Markowitz, 1952), in which the portfolio variance was minimized at a given rate of return (the average of positive rates of return of companies forming WIG20 was taken into account). Then, based on the values of the relative distance $S_{i}$, non-effective portfolios were built (Pośpiech, 2020a), and their results were compared with the effective portfolios and the market portfolio represented by the WIG20 index. 


\section{Results of empirical analysis}

The use of selected multi-criteria methods made it possible to obtain the rankings presented in Table 1.

Table 1.

Values of the $S_{i}$ indicator and rankings according to method of pre-selection

\begin{tabular}{|c|c|c|c|c|}
\hline \multirow{3}{*}{ Ranking } & \multicolumn{4}{|c|}{$S_{i}$ according to the methods } \\
\hline & \multicolumn{2}{|c|}{ TOPSIS } & \multicolumn{2}{|c|}{ FTOPSIS } \\
\hline & Company & $S_{i}$ & Company & $S_{i}$ \\
\hline 1 & $\mathrm{CCC}$ & 0.968 & $\mathrm{CCC}$ & 0.792 \\
\hline 2 & LPP & 0.856 & LPP & 0.686 \\
\hline 3 & EUR & 0.724 & PKN & 0.617 \\
\hline 4 & PKN & 0.723 & EUR & 0.586 \\
\hline 5 & PZU & 0.663 & PZU & 0.574 \\
\hline 6 & CPS & 0.644 & CPS & 0.538 \\
\hline 7 & PGN & 0.643 & PGN & 0.534 \\
\hline 8 & LTS & 0.630 & BZW & 0.531 \\
\hline 9 & BZW & 0.627 & PEO & 0.523 \\
\hline 10 & PEO & 0.619 & $\mathrm{PKO}$ & 0.510 \\
\hline 11 & $\mathrm{ACP}$ & 0.607 & MBK & 0.509 \\
\hline 12 & $\mathrm{PKO}$ & 0.604 & $\mathrm{ACP}$ & 0.506 \\
\hline 13 & MBK & 0.602 & LTS & 0.506 \\
\hline 14 & ENG & 0.600 & ALR & 0.503 \\
\hline 15 & ALR & 0.577 & ENG & 0.497 \\
\hline 16 & PGE & 0.576 & PGE & 0.443 \\
\hline 17 & OPL & 0.476 & TPE & 0.417 \\
\hline 18 & JSW & 0.473 & JSW & 0.381 \\
\hline 19 & $\mathrm{KGH}$ & 0.416 & OPL & 0.377 \\
\hline 20 & TPE & 0.241 & $\mathrm{KGH}$ & 0.290 \\
\hline
\end{tabular}

Adapted from: "The Risk of Multi-Criteria Portfolios Taking into Account the Fuzzy Approach" by E. Pośpiech, 2018.

According to research, in order to significantly reduce the unsystematic risk, the portfolio should contain from 10 to 15 instruments (Mayo, 2014). That is why, in the research, portfolios were constructed from sets containing ten to fifteen companies. The companies occupying the highest positions in the ranking were taken into account. Table 2 shows the sets of companies selected after the initial selection using TOPSIS and FTOPSIS methods.

Table 2.

The sets of companies - the basis of portfolio selection

\begin{tabular}{|l|c|c|c|c|c|c|}
\hline \multirow{3}{*}{ Methods } & \multicolumn{6}{|c|}{ Sets of companies } \\
\cline { 2 - 7 } & \multirow{2}{*}{$n=10$} & \multicolumn{4}{|c|}{$\begin{array}{r}\text { Companies successively attached to the previous group } \\
\text { in order to obtain a given number set }\end{array}$} \\
\cline { 2 - 8 } & $\begin{array}{l}\text { CCC, LPP, EUR, PKN, PZU, CPS, } \\
\text { PGN, LTS, BWZ, PEO }\end{array}$ & ACP & PKO & MBK & ENG & ALR \\
\hline FTOPSIS & $\begin{array}{c}\text { CCC, LPP, EUR, PKN, PZU, CPS, } \\
\text { PGN, PKO, BWZ, PEO }\end{array}$ & MBK & ACP & LTS & ALR & ENG \\
\hline
\end{tabular}

Source: Own study based on the data from the websites: www.bankier.pl, www.gpw.pl, http://infostrefa.com/infostrefa/pl/archiwum. 
Table 3 presents the designations of the effective portfolios generated during the research.

Table 3.

Designations of constructed effective portfolios

\begin{tabular}{|l|c|c|c|c|c|c|}
\hline \multirow{2}{*}{ Methods } & \multicolumn{6}{|c|}{ Designation of the portfolio depending on the pre-selection method and the size of the set } \\
\cline { 2 - 7 } & $n=10$ & $n=11$ & $n=12$ & $n=13$ & $n=14$ & $n=15$ \\
\hline TOPSIS & $\mathrm{P} 1$ & $\mathrm{P} 3$ & $\mathrm{P} 5$ & $\mathrm{P} 7$ & $\mathrm{P} 9$ & $\mathrm{P} 11$ \\
\hline FTOPSIS & $\mathrm{P} 2$ & $\mathrm{P} 4$ & $\mathrm{P} 6$ & $\mathrm{P} 8$ & $\mathrm{P} 10$ & $\mathrm{P} 12$ \\
\hline
\end{tabular}

Source: Own study.

Twelve portfolios were built (for 03/01/2018), with P7 = P8 and P11 = P12. It was examined how the performance of the portfolios developed in comparison to the market portfolio (marked as PM) throughout the next year (2018). The results are presented in Figures 1-6.

\section{Profits/losses of portfolios}

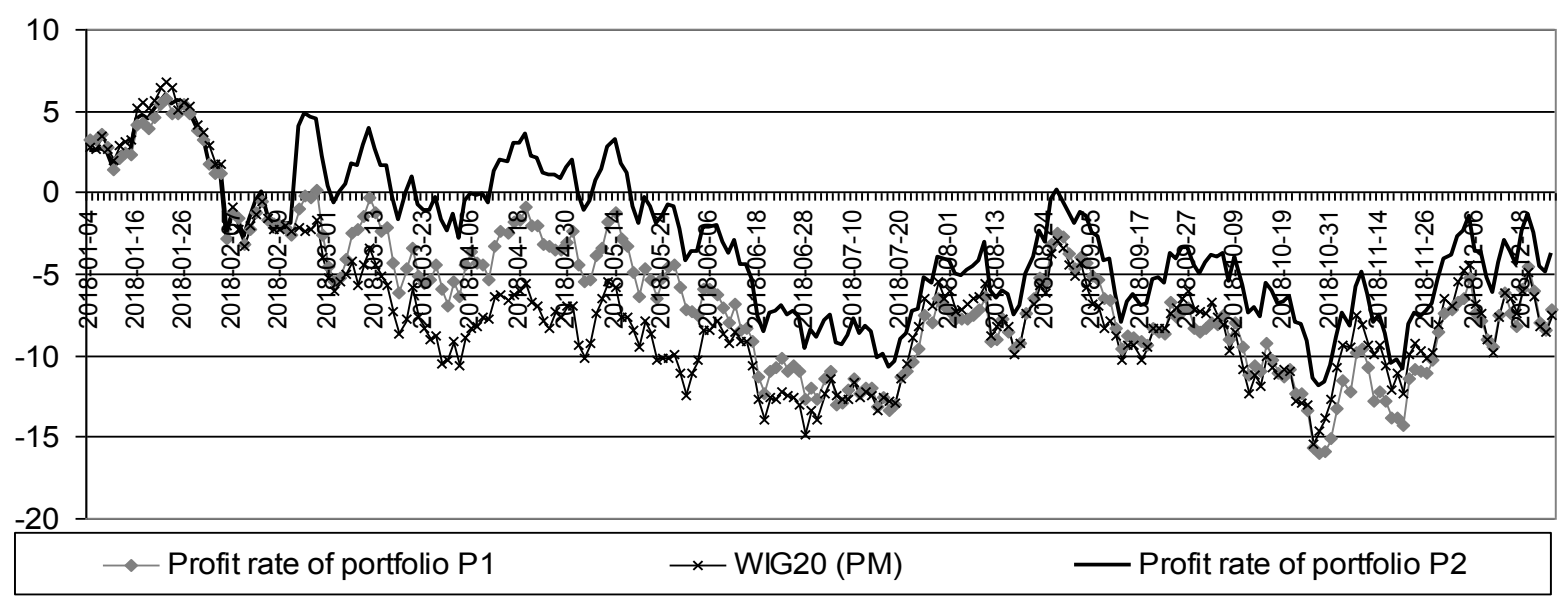

Figure 1. Profits/losses of portfolios P1, P2 $(n=10)$ and PM. Source: Own study based on the data from the websites: www.bankier.pl, www.gpw.pl, http://infostrefa.com/infostrefa/pl/archiwum.

Profits/losses of portfolios

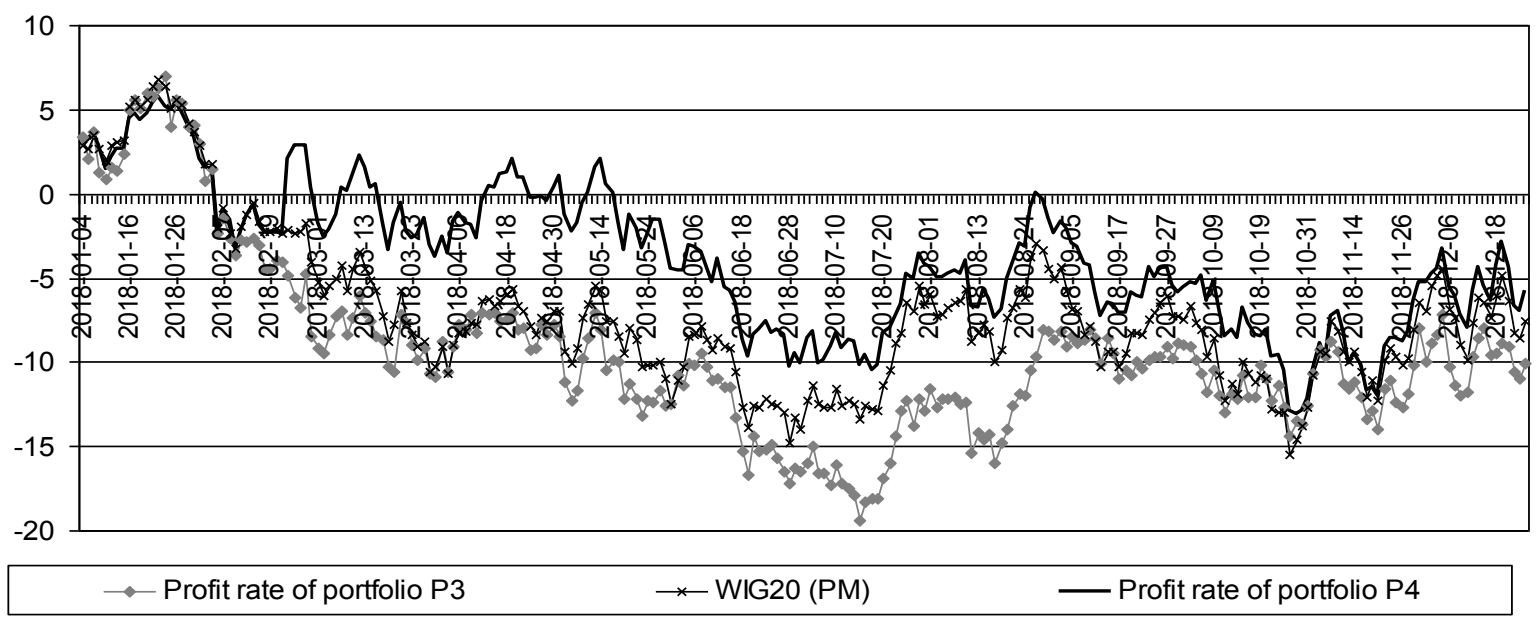

Figure 2. Profits/losses of portfolios P3, P4 $(n=11)$ and PM. Source: Own study based on the data from the websites: www.bankier.pl, www.gpw.pl, http://infostrefa.com/infostrefa/pl/archiwum. 
Profits/losses of portfolios

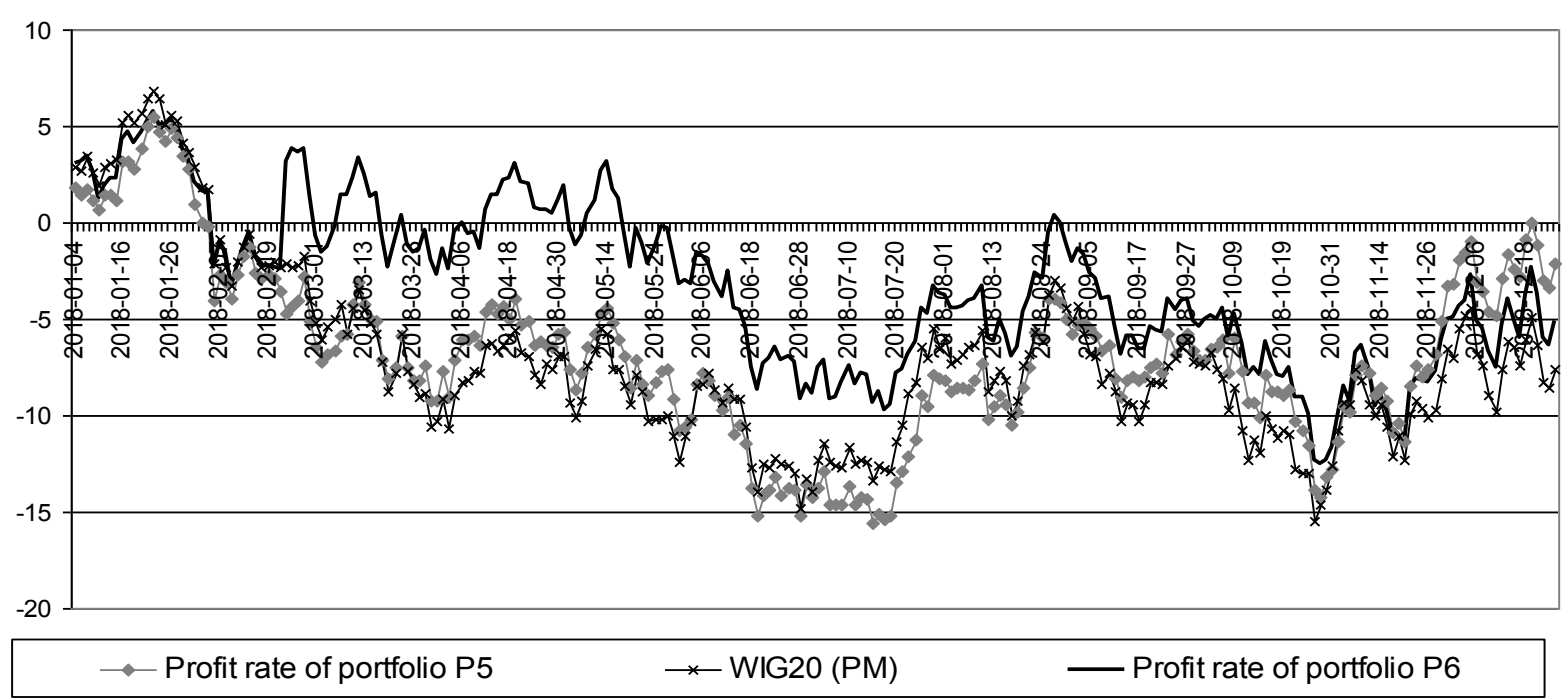

Figure 3. Profits/losses of portfolios P5, P6 $(n=12)$ and PM. Source: Own study based on the data from the websites: www.bankier.pl, www.gpw.pl, http://infostrefa.com/infostrefa/pl/archiwum.

Profits/losses of portfolios

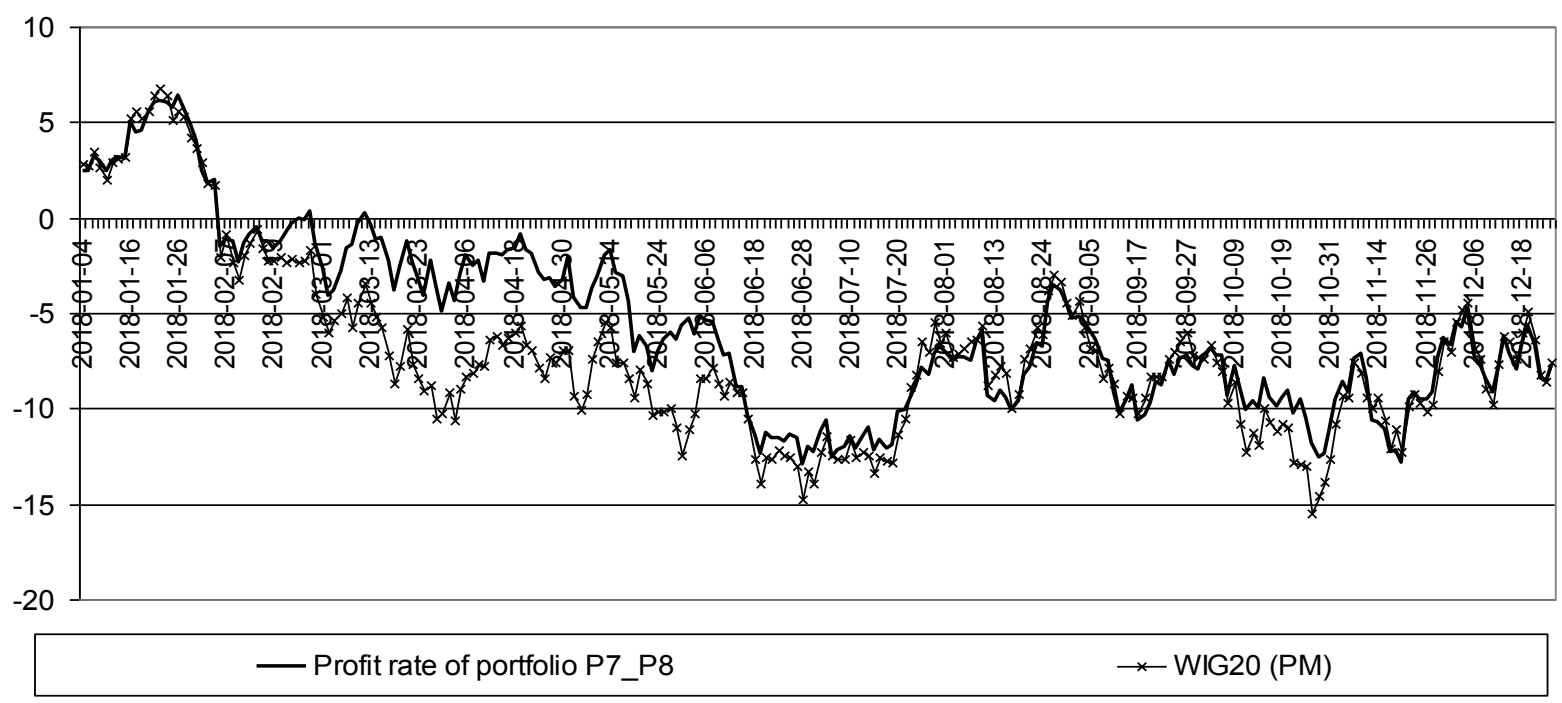

Figure 4. Profits/losses of portfolios P7 = P8 $(n=13)$ and PM. Source: Own study based on the data from the websites: www.bankier.pl, www.gpw.pl, http://infostrefa.com/infostrefa/pl/archiwum. 
Profits/losses of portfolios

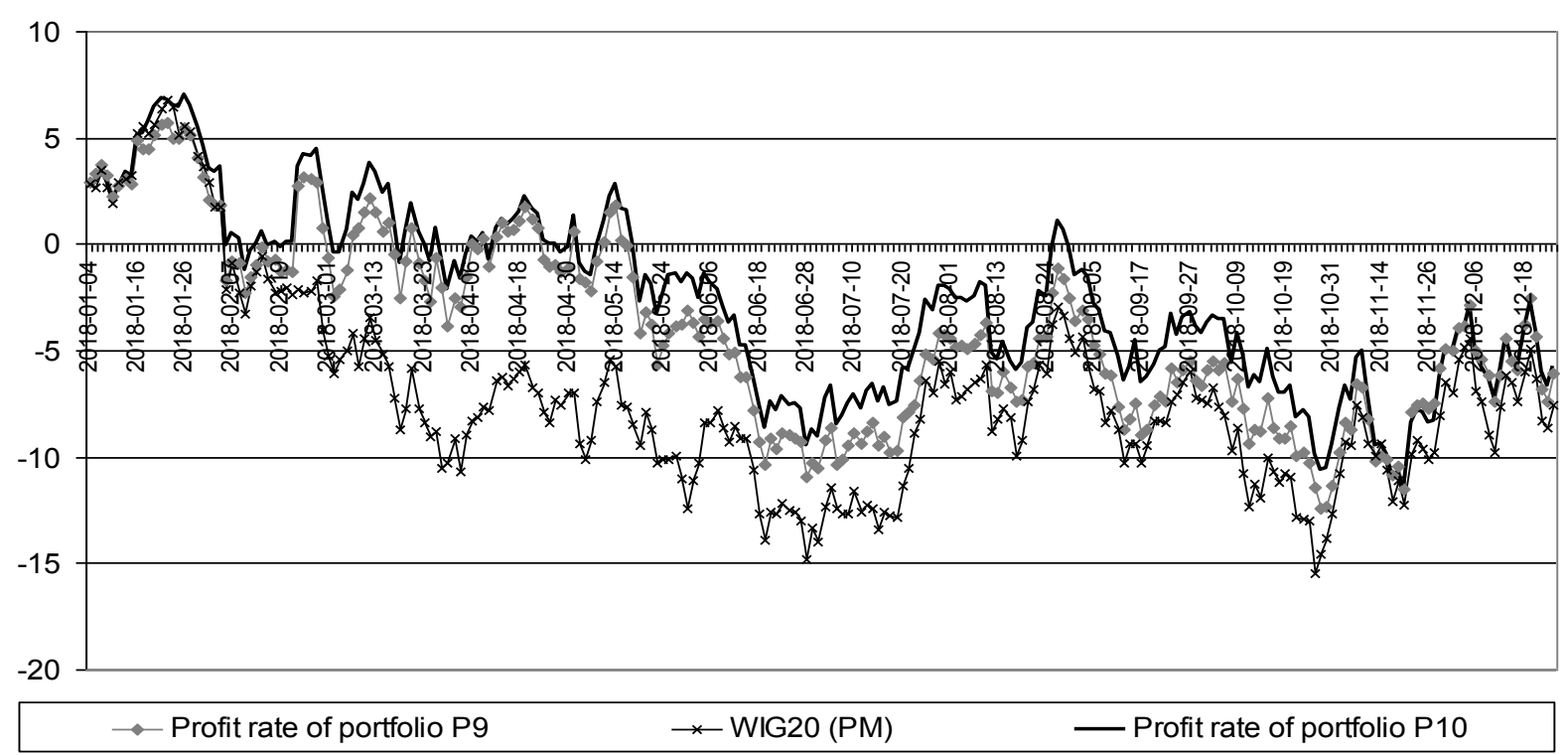

Figure 5. Profits/losses of portfolios P9, P10 $(n=14)$ and PM. Source: Own study based on the data from the websites: www.bankier.pl, www.gpw.pl, http://infostrefa.com/infostrefa/pl/archiwum.

Profits/losses of portfolios

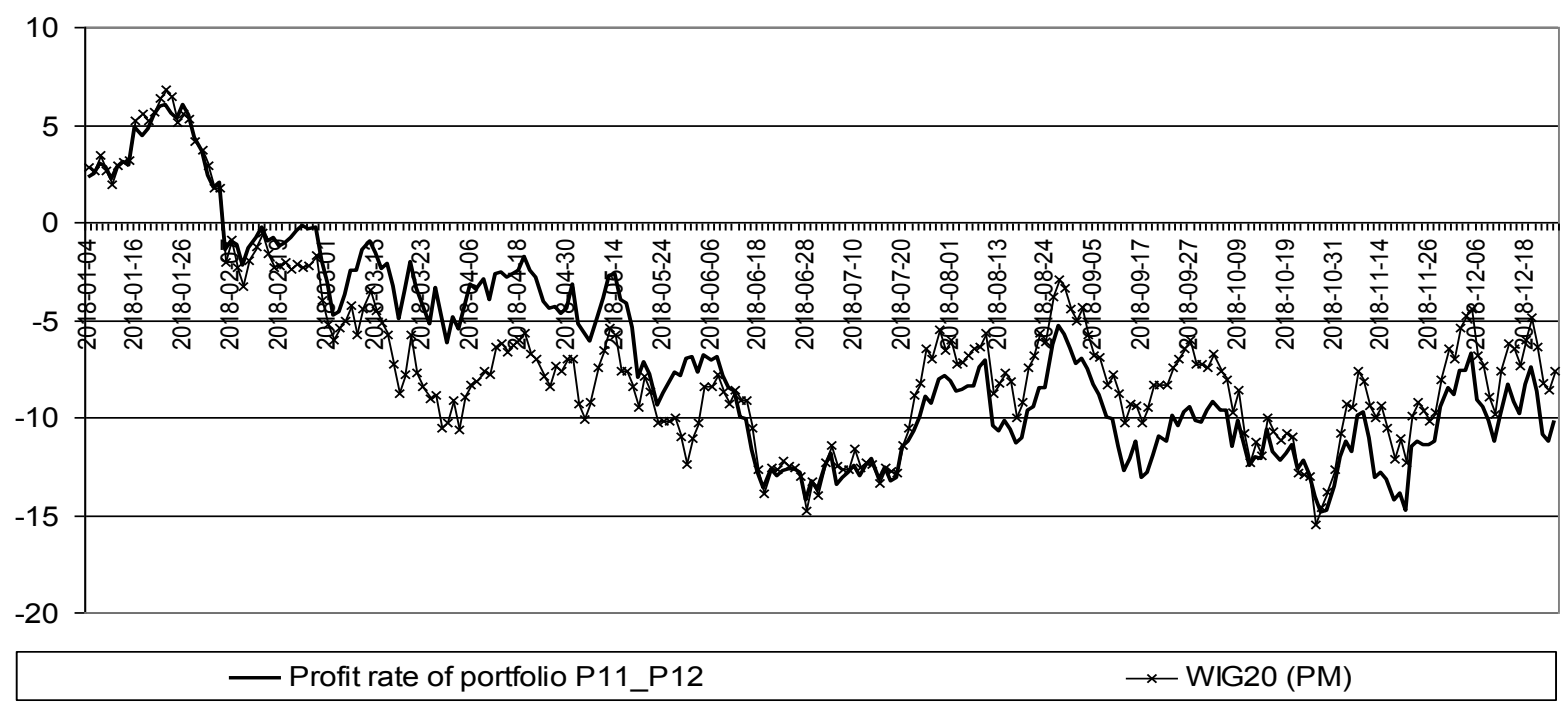

Figure 6. Profits/losses of portfolios P11 = P12 $(n=15)$ and PM. Source: Own study based on the data from the websites: www.bankier.pl, www.gpw.pl, http://infostrefa.com/infostrefa/pl/archiwum.

Conclusions for the effective portfolios:

- $n=10$ - almost throughout the entire period, the P1 portfolio records similar or better results than the market portfolio, the $\mathrm{P} 2$ portfolio recorded definitely the best results (until May it records even several percent profits);

- $n=11$ - the P3 portfolio in the first half of 2018 records comparable results with PM, then slightly worse, the $\mathrm{P} 4$ portfolio again records better results than the other two throughout the entire period; 
- $n=12$ - the P5 portfolio and the market portfolio PM are comparable, the P6 portfolio shows better results until the end of October 2018;

- $n=13-$ the P7 and P8 portfolios are identical, and for the longer period of 2018 they record no worse results than the market portfolio;

- $n=14$ - in the first half of 2018, the P10 portfolio records no worse results than P9 and definitely better than PM, in the second half of the year the differences between the portfolios results are smaller, but P10 usually records lower losses;

- $n=15-\mathrm{P} 11$ and P12 portfolios are the same - until the end of May 2018 they record comparable profits or lower losses than PM, while in the later period the PM portfolio performs no worse than the effective portfolios.

The presented results show that better results (higher profits or lower losses) are recorded by effective portfolios from the population selected using the FTOPSIS method, however, the observed losses, especially in the second half of the analyzed year, may suggest the need to reconstruct the portfolio after 5-6 months after its construction, which it will certainly improve its results (Pośpiech, 2020b).

The question is, if with the approach used, it is possible to obtain portfolios with better performance. The concept of building (non-effective) portfolios emerged, the structure of which was determined on the basis of the value of the relative distance measure $S_{i}$ - the value of the ratio in relation to the sum values of all ratios included in the portfolio is the share of the stock in the portfolio (Pośpiech, 2020a). The results of portfolios constructed in this way are shown in Figures 7-12 (portfolio designations are similar to those in Table 3 with the annotation "nef"). Additionally, they were compared with the effective portfolios that obtained the best results.

Profits/losses of portfolios

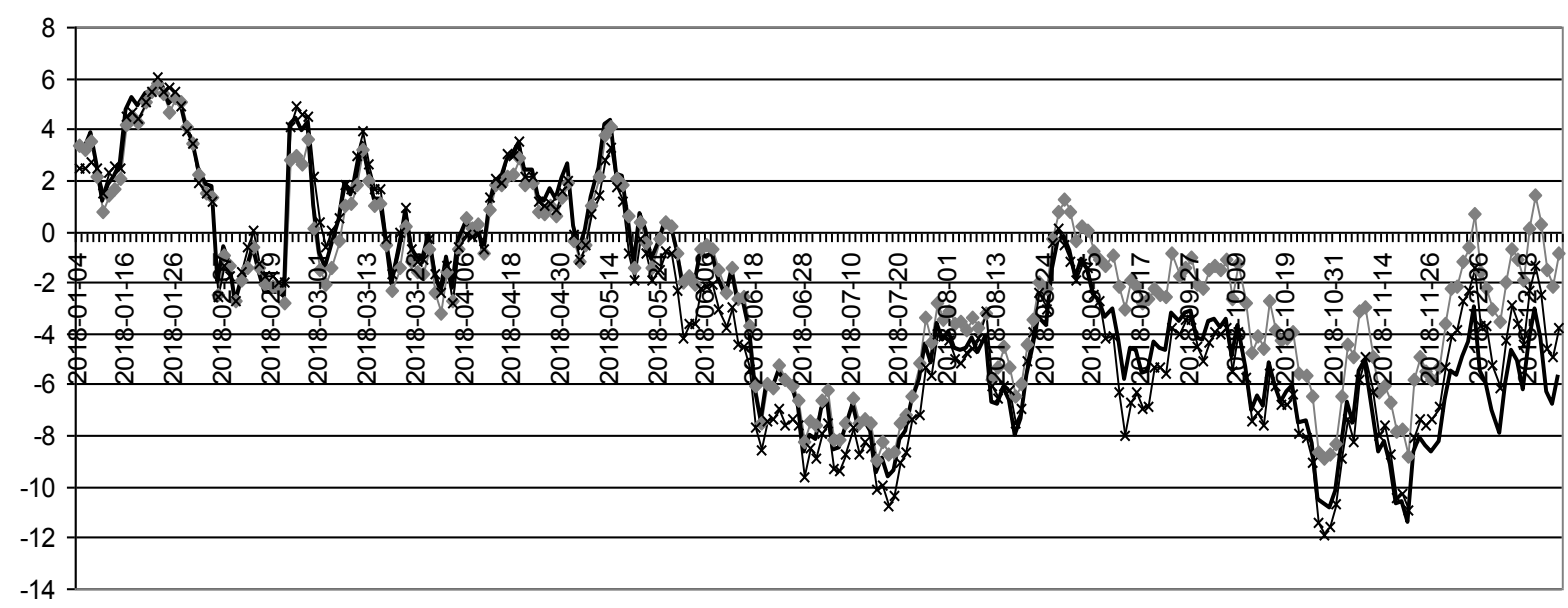

$\rightarrow-$ Profit rate of portfolio P1nef $\quad$ - Profit rate of portfolio P2nef $\quad \rightarrow$ Profit rate of portfolio P2

Figure 7. Profits/losses of portfolios P1nef, P2nef $(n=10)$ and P2. Source: Own study based on the data from the websites: www.bankier.pl, www.gpw.pl, http://infostrefa.com/infostrefa/pl/archiwum. 


\section{Profits/losses of portfolios}

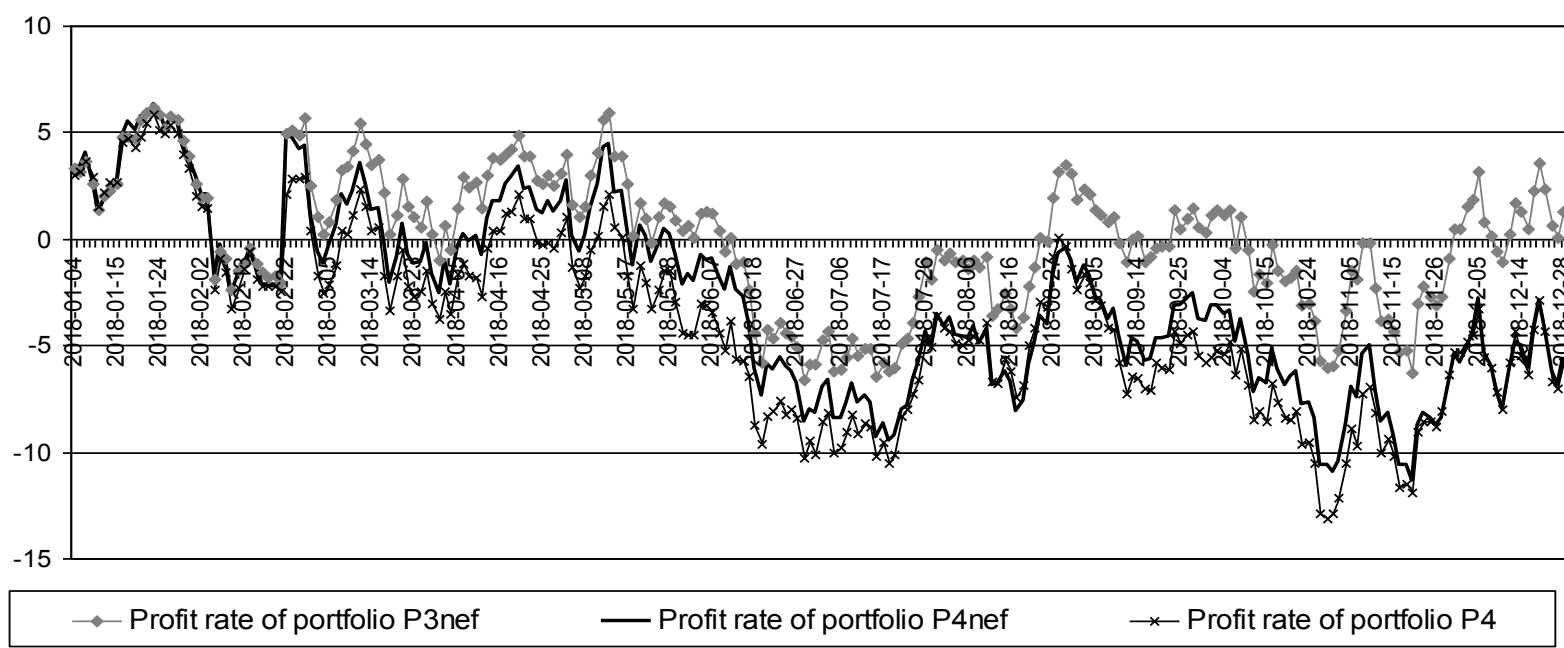

Figure 8. Profits/losses of portfolios P3nef, P4nef $(n=11)$ and P4. Source: Own study based on the data from the websites: www.bankier.pl, www.gpw.pl, http://infostrefa.com/infostrefa/pl/archiwum.

\section{Profits/losses of portfolios}

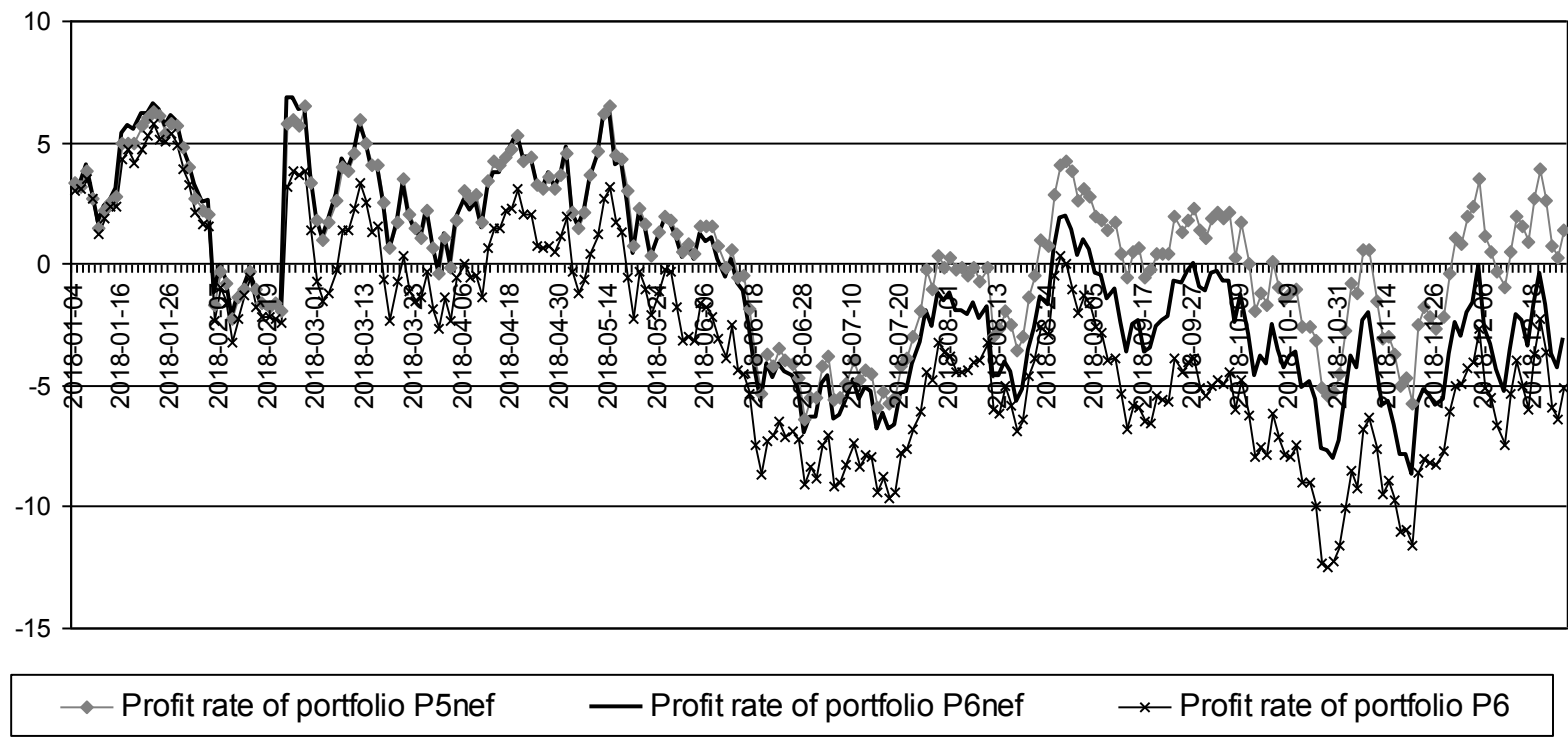

Figure 9. Profits/losses of portfolios P5nef, P6nef $(n=12)$ and P6. Source: Own study based on the data from the websites: www.bankier.pl, www.gpw.pl, http://infostrefa.com/infostrefa/pl/archiwum. 


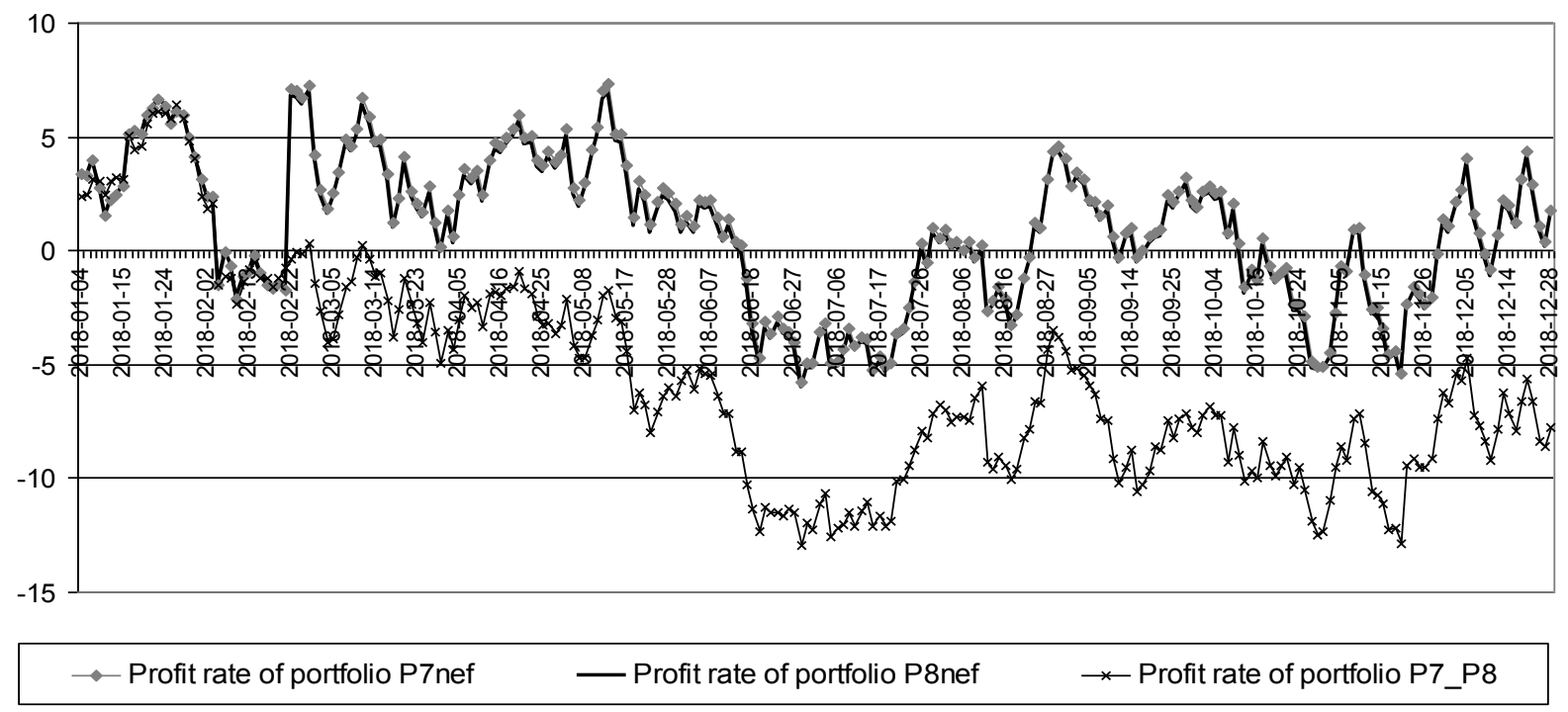

Figure 10. Profits/losses of portfolios P7nef, P8nef $(n=13)$ and P8. Source: Own study based on the data from the websites: www.bankier.pl, www.gpw.pl, http://infostrefa.com/infostrefa/pl/archiwum.

Profits/losses of portfolios

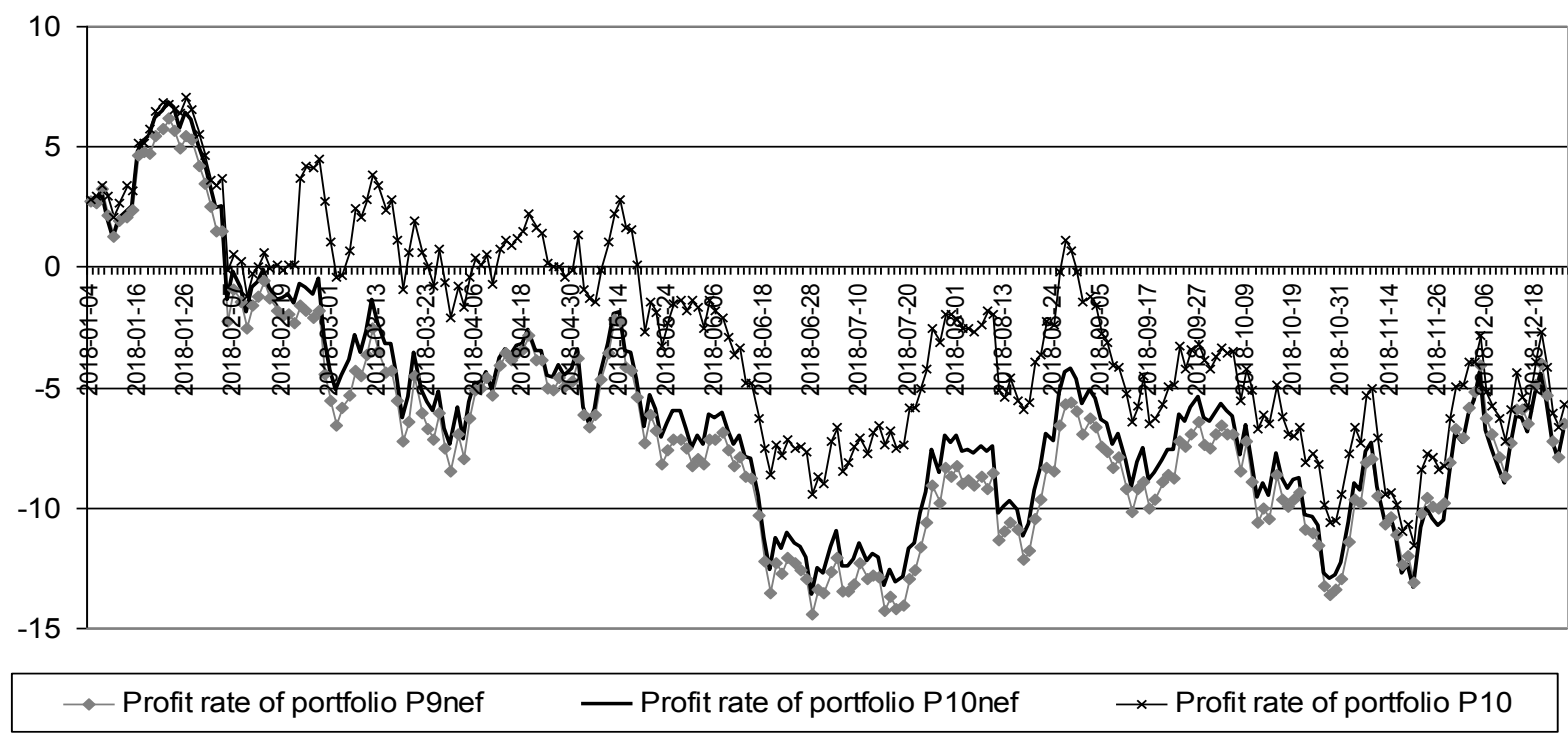

Figure 11. Profits/losses of portfolios P9nef, P10nef $(n=14)$ and P10. Source: Own study based on the data from the websites: www.bankier.pl, www.gpw.pl, http://infostrefa.com/infostrefa/pl/archiwum. 
Profits/losses of portfolios

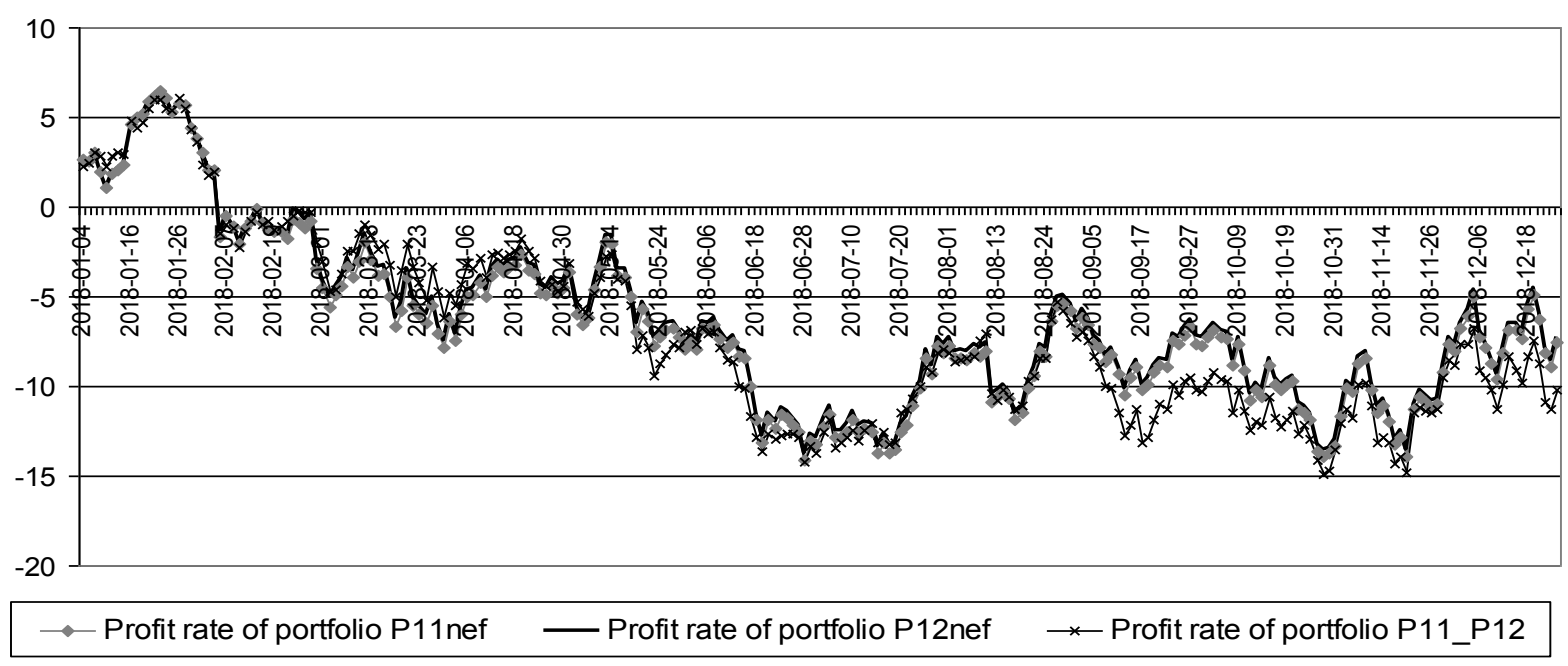

Figure 12. Profits/losses of portfolios P11nef, P12nef $(n=15)$ and P12. Source: Own study based on the data from the websites: www.bankier.pl, www.gpw.pl, http://infostrefa.com/infostrefa/pl/archiwum.

Conclusions for non-effective portfolios:

- $n=10$ - until the end of August 2018, all portfolios recorded similar results, since September, the P1nef portfolio recorded better results (mainly lower losses);

- $n=11$ - the P4nef portfolio outperformed the P4 throughout the year, but the P3nef portfolio was the best;

- $n=12$ - throughout 2018, the non-effective portfolios P5nef and P6nef recorded better results (mostly profits) than P6, in the first half of the year the results of non-effective portfolios were comparable, while in the second half of the year the best results were achieved by the P5nef portfolio;

- $n=13$ - non-effective portfolios record similar results, and definitely better than P8 (most of them record profits throughout the period);

- $n=14$ - non-effective portfolios record similar results, but this time P10 has better results;

- $n=15-$ all three portfolios record comparable results, a little bit better are the noneffective ones.

\section{Summary}

The conducted analyzes showed that effective portfolios generated from the sets selected as a result of the preliminary multi-criteria procedure most often record better results compared to the market portfolio (higher profits or lower losses). This regularity is visible especially in the 
first half of 2018, which means that after this period, the portfolio structure should be modified. The best in this comparison is the portfolio selected after the companies selection made using the FTOPSIS method. The obtained effective portfolios mainly recorded little gains or losses, therefore the concept of using the relative distance values obtained under the multi-criteria procedure to determine the portfolio structure was developed. The non-effective portfolios constructed on their basis, in most of the considered cases, recorded better results (much smaller losses or significantly higher profits) - the only exception was the portfolio consisting of 14 shares. Moreover, using the proposed concept, the portfolios selected on the basis of $S_{i}$ values obtained by the TOPSIS method had better or at least not worse results.

The analyses showed once again that the ordering of companies using the FTOPSIS method and building effective portfolios on this basis enables generating of portfolios with better results than the market portfolio. However, non-effective portfolios constructed on the basis of $S_{i}$ value may generate even better results - this time the portfolios obtained using the standard TOPSIS method as a pre-selection method are more attractive. Although the results are not unequivocal, they seem promising, and there are many indications that the proposed portfolio selection concept may actually enable the generation of attractive portfolios. Nevertheless, the presented idea requires further research.

\section{References}

1. Chen, C.T., and Hung, W.Z. (2009). A New Decision-Making Method for Stock Portfolio Selection Based on Computing with Linguistic Assessment. Journal of Applied Mathematics and Decision Science. doi: http://dx.doi.org/10.1155/2009/897024.

2. Ece, O., and Uludag, A.S. (2017). Applicability of Fuzzy TOPSIS Method in Optimal Portfolio Selection and an Application in BIST. International Journal of Economics and Finance, 9(10), 107-127. doi: https://doi.org/10.5539/ijef.v9n10p107.

3. http://infostrefa.com/infostrefa/pl/archiwum, 15.09.2020.

4. Hwang, C. L., and Yoon, K. (1981). Multiple Attribute Decision Making: Methods and Application. Berlin: Springer Verlag.

5. Jahanshahloo, G.R., Hosseinzadeh Lotfi, F., and Izadikhah, M. (2006). Extension of the TOPSIS Method for Decision-making Problems with Fuzzy Data. Applied Mathematics and Computation, 181(2), 1544-1551. doi: http://dx.doi.org/10.1016/j.amc.2006.02.057.

6. Jajuga, K., and Jajuga, K. (2015). Inwestycje - Instrumenty finansowe. Aktywa niefinansowe. Ryzyko finansowe. Inżynieria finansowa. Warszawa: PWN.

7. Kazemi, A., Sarrafha, K., and Bedel, M. (2014). A hybrid fuzzy decision making method for a portfolio selection: A case study of Tehran Stock Exchange. International Journal of 
Industrial and Systems Engineering, 18(3), 335-354. doi: http://dx.doi.org/10.1504/ IJISE.2014.065537.

8. Lai, Y.J., Liu, T.Y., and Hwang C.L. (1994). TOPSIS for MODM. European Journal of Operational Research, 76(3), 486-500. doi: http://dx.doi.org/10.1016/0377-2217(94) 90282-8.

9. Leszczyński, Z. (2004). Analiza ekonomiczno-finansowa spółki. Warszawa: PWE.

10. Liu, Y.J., Zhang, W.G., and Xu, W.J. (2012). Fuzzy multi-period portfolio selection optimization models using multiple criteria. Automatica, 48(12), 3042-3053. doi: http://dx.doi.org/10.1016/j.automatica.2012.08.036.

11. Markowitz, H.M. (1952). Portfolio selection. Journal of Finance, 7(1), 77-91. doi: http://dx.doi.org/10.2307/2975974.

12. Mayo, H.B. (2014). Inwestycje. Warszawa: PWN.

13. Nguyen, T.T., and Gordon-Brown, L.N. (2012). Fuzzy Numbers and MCDM Methods for Portfolio Optimization. International Journal of Computer, Electrical, Automation, Control and Information Engineering, 6(12), 1593-1605.

14. Pośpiech, E. (2017a). Multi-criteria fuzzy modelling in the issue of portfolio selection. In: M. Čulik (ed.), Financial Management of Firms and Financial Institutions 2017. Proceeding (Part III) (pp. 700-707). Ostrava: VŠB-TU.

15. Pośpiech, E. (2017b). Rozmyte modelowanie we wspomaganiu decyzji inwestycyjnych. Organizacja i Zarzadzanie, 113, 375-384.

16. Pośpiech, E. (2018). The Risk of Multi-Criteria Portfolios Taking into Account the Fuzzy Approach. In: M. Čulík (ed.), Managing and Modelling of Financial Risks. 9th International Scientific Conference - Proceedings (Part 2) (pp. 411-418). Ostrava: VŠB-TU.

17. Pośpiech, E. (2020a). Modelowanie nieostre $w$ wielokryterialnym wspomaganiu decyzji inwestycyjnych. Katowice: Wydawnictwo Uniwersytetu Ekonomicznego.

18. Pośpiech, E. (2020b). The Multi-criteria Fuzzy Approach to Building and Evaluating Effective Portfolios. Organizacja i Zarzadzanie, 144, 397-407.

19. Pośpiech, E., and Mastalerz-Kodzis, A. (2015). Wybór metody wielokryterialnej do wspomagania decyzji inwestycyjnych. Organizacja i Zarządzanie, 86, 379-388.

20. Pośpiech, E., and Mastalerz-Kodzis, A. (2016). Zastosowanie metody TOPSIS w ujęciu rozmytym do selekcji walorów giełdowych. Organizacja i Zarządzanie, 96, 395-404.

21. Raei, R., Bahrani Jahromi, M. (2012). Portfolio optimization using a hybrid of fuzzy ANP, VIKOR and TOPSIS. Management Science Letters, 2, 2473-2484. doi: http://dx.doi.org/ 10.5267/j.ms1.2012.07.019.

22. Roszkowska, E., Wachowicz, T. (2013). Metoda TOPSIS i jej rozszerzenia - stadium metodologiczne. In: T. Trzaskalik (ed.), Analiza wielokryterialna. Wybrane zagadnienia (pp. 11-40). Katowice: Uniwersytet Ekonomiczny.

23. Sprawozdania finansowe rozważanych spólek z lat 2015-2017. Retrieved from: http://www.money.pl/gielda/spolki-gpw/, 15.09.2020. 
24. Tarczyński, W. (2001). Rynki kapitałowe. Metody ilościowe. Warszawa: Polska Agencja Wydawnicza PLACET.

25. Tarczyński, W. (2002). Fundamentalny portfel papierów wartościowych. Warszawa: PWE.

26. Trzaskalik, T. (ed.) (2006). Metody wielokryterialne na polskim rynku finansowym. Warszawa: PWE.

27. Trzaskalik, T. (ed.) (2014). Wielokryterialne wspomaganie decyzji. Warszawa: PWE.

28. Tyran, M.R. (2001). Wskaźniki finansowe. Kraków: Oficyna Ekonomiczna.

29. www.bankier.pl, 15.09.2020.

30. www.gpw.pl, 15.09.2020. 